\title{
standing against all odds
}

I was born in a small town of Punjab, India. My father was in army. After a few years of retirement, he passed away. My mother is a house wife. I have 3 brothers and an elder sister. All of them are married. All of them are healthy and there is no congenital history of any kind of blindness.

Since my childhood I didn't have any disease or severe illness. I studied in my home town and in 1990, got admission in BSC Nursing at Christian Medical College (CMC), Ludhiana (Punjab). Suddenly, during the final examination of fourth semester, I suffered from fever and cervical pain. The doctor diagnosed it as cervical pain and prescribed some medicine along with bed rest. I also thought it to be a minor problem as I was really busy with my exams and they were my priority at that time. After 15 days, my exams got were over and I went back home. My father took me to the doctor where I was told that I was suffering from Typhoid and didn't get proper treatment by the previous doctor. I took medicine for one week but still suffered from fever and headache. One morning, I had a very serious attack of headache accompanied with vomiting. I was admitted in the civil hospital, Gurdaspur, Punjab. The doctor examined my eyes and body movements and by evening I was quite alright. I took light dinner with my parents and slept. During midnight, I again had very severe headache for which the doctor gave me an injection. Till that time my eye sight was alright. I had seen my parents and the doctor. I didn't get any relief and after two hours, the doctor gave me another injection after which I was not fully conscious. Next evening I was shifted to Government hospital, Amritsar. I remained there for 5 days but there was no improvement. So I was shifted to CMC, Ludhiana. The doctors immediately commisioned the required tests and started IV treatment. They diagnosed me with Tubercular Meningitis. After 4 days of admission in this hospital, I became conscious and found myself complaining of darkness and often thought this could be because the lights were switched off I have lost total vision due to bilateral atrophy of optic nerves and they were not sure that whether I will be able to see again or not. We were not aware of the complications of this disease. The doctors gave us hope that within a year I will be able to see. So I was very hopeful. My treatment continued for one and a half years from the same hospital. During this period, we consulted various reputed hospitals. During my last visit to the hospital, one doctor, from Department of Neurology explained on asking that I wil not regain my vision and counseled me to join a rehabilitation centre. That moment was very depressing for me and felt like everything had come to an end. My world became gloomy and scary. It was very difficult for me to accept this tragedy; however, I faced the odd situation with courage and determination. It is my unswerving resolution, optimism and the support of my family that helped me to proceed further to search for a happier life with a bright future.

I joined a vocational rehabilitation training centre in 1995 in Ludhiana and learnt special living, reading and writing skills. Initially, I faced a number of difficulties for adjusting to the new environment. It is not possible for me to express that experience in words. My family was also totally shattered. I did one year diploma in English Braille Stenography from the same rehabilitation centre. After that I was appointed as a stenography teacher in the same institute. In May 1997, I joined the Institute for the Blind, Sector 26, Chandigarh, as a Work Experience teacher. I worked with full devotion for teaching Braille typing and shorthand to visually impaired students. I continued my education simultaneously. As I couldn't complete my BSC, I joined B.A. After that I did M.A. in Sociology and secured second position in Panjab University, Chandigarh. I also qualified the UGC examination in 2005 and enrolled for Ph.D in 2006, under the guidance of Dr. Madhurima Verma, Professor Dept of sociology (USOL), Punjab University, Chandigarh.

But all this was not easy. I faced many hindrances in the path of educational achievements, such as the unavailability of study materials in Braille or audio format, difficulty in finding readers and writers, etc. I did not lose hope and continued with determination to attain higher education, and completed my doctoral thesis in 2011. I worked as a teacher in the Institute for the Blind, Chandigarh for 15 years. In 2011, I got selected as an
Assistant Professor (Dept of Sociology), Punjabi University, Patiala. I use computer with the help of a screen reading software which also helps me in preparing lectures for the students. I got married in 2009 and I am blessed with a daughter. I think with positive attitude, strong determination, family and social support, the right opportunity and faith in God, one can face the odds and move ahead in life. Although I am leading a happy life but the truth is that no happiness in this world can replace my lost vision. I still hope that with advancement in medical science and research, new inventions will result in resolving vision problem.

doi : 10.5214/ans.0972.7531.190302

Kiran Guru, PhD

Department of Physiology

Punjabi University, Patiala

INDIA 